\title{
Iwona WOJTKIEWICZ
}

\section{EKSPRESYWNIE O CZŁOWIEKU \\ W SŁOWNICZKU GWARY AUGUSTOWSKIEJ ALEKSANDRA OSIPOWICZA}

Teresa Skubalanka określa ekspresywność jako uwydatnienie, obok funkcji reprezentatywnej, również funkcji ekspresywno-impresywnej znaku językowego ${ }^{1}$. W myśl tej definicji, każdy znak ekspresywny oprócz podstawowej funkcji reprezentatywnej ujawnia również postawę nadawcy, a więc wyraża elementy emocji, oceny itp. Stanisław Grabias za ekspresywne uznaje $z$ kolei te znaki semiotyczne, za których pomocą nadawca wyraża swój stosunek do otaczających go zjawisk, lub w których - niezależnie od intencji nadawcy - przejawiają się cechy jego osobowości ${ }^{2}$. Stwierdza zarazem, że ekspresywność językowa polega na obecności ekspresywnego komponentu w obrębie znaczenia znaku lub w obrębie jego obudowy semantycznej, jaką jest informacja w wypowiedzi lub sens w wyrazie. Autor zauważa jednak, że znacznie częściej ekspresywność utożsamia się i pojmuje jako uczuciową ocenę zjawisk $^{3}$.

W obrębie wyrazów emocjonalnych można wyróżnić formacje o eksplicytnych wykładnikach emocjonalności oraz wyrazy, w których emocjonalność tkwi implicite. Komponentem wielu wyrazów nacechowanych emocjonalnie i zarazem wykładnikiem emocjonalności są formanty wyspecjalizowane $\mathrm{w}$ urabianiu formacji ekspresywnych typu -och, -ol, -uch, -as. Niekiedy wykładnikiem emocjonalności bywają zmiany znaczeniowe wyrazów, widoczne najwyraźniej w przenośniach sferycznych, występują też formacje nacechowane, w których brakuje

\footnotetext{
1 T. Skubalanka, O ekspresywności języka, Annales UMCS, Sectio F, vol. XXVII, Lublin 1972.

2 S. Grabias, Pojęcie ekspresywnego znaku językowego, w: Z zagadnień słownictwa współczesnego języka polskiego, Wrocław 1978, s. 107.

3 Tamże, s. 115.
} 
jakiegokolwiek zewnętrznego wykładnika emocjonalności - tkwi ona $\mathrm{w}$ nich implicite ${ }^{4}$.

W wielu wypadkach przy określaniu wartości ekspresywnej nazw nacechowanych emocjonalnie napotykamy trudności, związane $\mathrm{z}$ niemożnością określenia charakteru gramatycznego i znaczenia podstawy słowotwórczej. Nie pozwalają one stwierdzić jednoznacznie czy wartość ekspresywna derywatu jest związana z sufiksem, czy też posiada inny wykładnik emocjonalności. Na trudności w opisie gramatycznym słownictwa nacechowanego emocjonalnie i wszelkich przejawów ekspresji językowej zwracał uwagę już dość dawno temu Charles Bally5. Problem ten dostrzega S. Grabias, który wyraża opinię, że "orzekanie o ekspresywnej wartości formantu może odbywać się tylko po wyeliminowaniu innych aspektów ekspresji, które w konstrukcjach słowotwórczych mogą zachodzić (np. przeniesienie wartości emocjonalnej z wyrazu podstawowego na pochodny, nowość leksykalna, aluzja itp." 6 . Dyskusyjny charakter analizy nazw ekspresywnych podkreśla również Irena Szczepankowska, badająca nomina attributiva w gwarze łomżyńskiej’. Tak więc, wątpliwości związane $\mathrm{z}$ określeniem charakteru motywacji i funkcji formantu znacznie utrudniają systematyczny opis słownictwa ekspresywnego.

Nazwy osób wyróżniających się ze społeczności pewnymi cechami pozytywnymi lub - znacznie częściej - negatywnymi, stanowią szczególnie bogato reprezentowaną kategorię leksyki gwarowej, co znajduje odzwierciedlenie $\mathrm{w}$ licznych zbiorach słownictwa ogólnogwarowego, regionalnego i lokalnego ${ }^{8}$.

Materiał leksykalny zawarty $\mathrm{w}$ dziewiętnastowiecznym Słowniczku gwary augustowskiej Aleksandra Osipowicza obfituje w słownictwo ekspresywne o charakterze antropocentrycznym, a więc dotyczące różnych cech człowieka i jego postępowania. W zakresie nazw określających

\footnotetext{
4 Tamże, s. 114.

5 Ch. Bally, Mechanizm ekspresywności językowej, w: Stylistyka Bally'ego. Wybór tekstów, Warszawa 1966.

6 S. Grabias, O ekspresywności języka, Lublin 1980, s. 44.

7 I. Szczepankowska, Nomina attributiva $w$ gwarze tomżyńskiej, Białystok 1998.

8 Tamże, s. 15.
} 
człowieka ze względu na jego zachowanie, cechy fizyczne i psychiczne większość ma charakter wartościujący, sygnalizuje subiektywny stosunek nadawcy. $Z$ zasady zawarta jest $w$ nich ocena negatywna.

Reakcje emocjonalne wywołuje tu "inność" wobec powszechnie przyjętych cech stanowiących o „normalności”, odstępstwo od przyjętych norm obyczajowo-społecznych czy moralnych. Właściwości nacechowane dodatnio znacznie rzadziej podlegają ocenie nadawcy albo ujęte zostają przez pryzmat ironii, szyderstwa. Ciekawie przedstawia się wewnętrzna struktura nazw określających człowieka ze względu na jego postawę, wygląd i wartość etyczno-intelektualną. Można by powiedzieć, że w sposób swoisty odzwierciedla się w niej społeczna ocena typowych przywar ludzkich ${ }^{9}$.

Najczęściej już w samym desygnacie zawarty jest element ekspresji o różnorodnym nasyceniu emocjonalnym, przy czym uczuciowy stosunek mówiącego może mieć niezliczone odcienie (aprobata, współczucie, politowanie, niechęć, oburzenie, wrogość). Znajduje to odbicie w różnorodności środków językowych służących do wyrażania tych emocji. Są to derywacje słowotwórcze, alternacje fonetyczne w obrębie rdzenia lub formantu, procesy semantyczne, zwłaszcza metonimia i metafora ${ }^{10}$. Zdarza się też, że ekspresja tkwi w samym leksemie.

W Słowniczku gwary augustowskiej A. Osipowicza występuje około 130 nacechowanych emocjonalnie określeń, dotyczących cech i zachowania człowieka. Część leksyki ekspresywnej została opatrzona przez autora słowniczka kwalifikatorami. Są to przede wszystkim kwalifikacje typu: żartobliwe, pogardliwe, obelżywe, wzgardliwe, ironiczne. Mimo że $\mathrm{w}$ analizowanym źródle występuje również pozytywne wartościowanie, przejawiające się w kwalifikacjach takich, jak pieszczotliwe czy zdrobniałe, to $\mathrm{z}$ reguły nie dotyczy ono człowieka. Zdecydowana większość słownictwa ekspresywnego w Słowniczku gwary augustowskiej przejawia swoją wartość emocjonalną w licznych parakwalifikacjach. Nie brak również wyrazów, w których choć tkwi ekspresja, to nie ujawnia się ona $\mathrm{w}$ ich definicjach semantycznych.

9 D. Buttler, Kategorie semantyczne leksyki potocznej, w: Z zagadnień słownictwa..., s. 40.

10 Por. A. Kowalska, Z badań nad mazowieckim słownictwem ekspresywnym, w: Polszczyzna pótnocno-wschodnia. Metodologia badań językowych, red. B. Falińska, Wrocław Łódź 1989, s. 34. 
Uwzględnienie kryterium gramatycznego każe $\mathrm{w}$ badanym materiale wyróżnić przede wszystkim formacje rzeczownikowe, $\mathrm{w}$ tym złożenia, oraz wyraźnie mniej liczne konstrukcje przymiotnikowe i czasownikowe. Oddzielną kategorię tworzą frazeologizmy.

Rzeczownikowe formacje ekspresywne zostały utworzone w większości od podstaw słowotwórczych o ujemnym nacechowaniu emocjonalnym za pomocą derywacji sufiksalnej. Wykorzystano w niej zarówno formanty neutralne emocjonalnie (np. $-a k,-a c z,-e c)$, jak i takie, które zwykle tworzą formacje nacechowane ujemnie (np. -on, -och, -uch, -ot). W niektórych wypadkach pejoratywne formacje ekspresywne zostały utworzone za pomocą formantów nacechowanych dodatnio (np. -ik, $-y k,-e k)$. Jednak najczęściej to nie formanty, a ujemnie nacechowane wyrazy podstawowe, rozstrzygają o pejoratywności zabarwienia emocjonalnego formacji pochodnych. Proces derywacji słowotwórczej powoduje nasilenie stopnia tej pejoratywności, przy czym rodzaj nacechowania samego formantu (neutralne, ujemne, dodatnie) nie zawsze rozstrzyga o stopniu pejoratywnego nacechowania formacji pochodnej ${ }^{11}$.

Najbardziej produktywny $\mathrm{w}$ tworzeniu określeń pejoratywnych $\mathrm{w}$ materiale słownikowym Osipowicza jest sufiks: -ak. Utworzone formacje są wynikiem skojarzenia ujemnie wartościującej podstawy i obojętnie nacechowanego formantu i odznaczają się dużym ładunkiem emocjonalnym: gomolak 'człowiek o rysach niewydatnych', pochmulak 'człowiek ponury i milczący', podrusiniak 'tak nazywają Prusaki ironicznie mieszkańców Augustowa', rozdziawiak 'gap, mający wiecznie otwarte usta', Rusak 'Rosjanin', pakulak 'mający włosy rozczochrane, do pakuł podobne', szturmak 'dziewka lub kobieta niezdarna', umarlak 'człowiek umarły', wyszczerzak 'człowiek ciągle śmiejący się, bufon wioskowy, wyśmiewający wszystkich', zmarźlak 'ten, co rychło marznie', tamzak 'szubrawiec, żyd zmizerowany i biedny', niemak 'człowiek niemy'. Wyjątkiem wśród tej grupy wyrazów jest określenie swojak 'krewny lub powinowaty', o pozytywnym zabarwieniu emocjonalnym,

11 Por. S. Grabias, Derywacja a ekspresja, w: Studia nad składniq polszczyzny mówionej, Wrocław 1978, s. 100. 
utworzone od pozytywnie wartościującej podstawy słowotwórczej za pomocą formantu $-a k$.

Znacznie mniejszą produktywnością odznaczają się wielofunkcyjne formanty -acz: chamacz 'człowiek mówiący niewyraźnie, przez nos', cichacz 'z cicha pęk, człowiek skryty', maniuchacz 'mańkut'; -ec: połamaniec 'człowiek ułomny, połamany', zaprzaniec 'odstępca, renegat'; -stwo: dreństwo 'lichota, gałgaństwo, dran'.

W wielu wypadkach rozstrzyganie o motywacyjnej roli formantu wydaje się niemożliwe albo mało skuteczne. Występują co prawda nieliczne formacje, które są połączeniem negatywnie wartościującej podstawy i ujemnie nacechowanego sufiksu, jednak już w samym rdzeniu najczęściej tkwi emocjonalność. Są to formacje $\mathrm{z}$ sufiksem -un: lizun 'pochlebca, zausznik', sysun 'dziecię przy piersi': -uch: piecuch 'niedołęga', pleciuch 'gaduła, plotkarz', obżartuch 'za dużo jedzący', -el: peckiel 'fuszer, partacz', fafel 'smarkacz'. Wyjątkowo mało produktywne są ujemnie nacechowane formanty -ich: łupich 'oprawca, zwany po miastach czyścicielem, hyclem, a. rakarzem'; -al: nosal 'posiadacz długiego a dużego nosa'; -ej: cielepiej 'gamoń'; -aj: mleczaj 'człowiek mający zajedzie w końcach ust'. Sporadycznie wyodrębnia się obcy sufiks -us, który jest na tyle zadomowiony $\mathrm{w}$ dziewiętnastowiecznej polszczyźnie, że może łączyć się z morfemami rdzennymi swojskimi, np.: cybulus 'człowiek nierozgarnięty, głupowaty', wyterus 'bezczelny nicpon', gadatywus 'gaduła'. W jednym wypadku (czyścioch 'osoba lubiąca czystość, szczególnie własnego ciała') ujemnie nacechowany sufiks -och łączy się z pozytywnie wartościującą podstawą, wobec czego określenie to, choć ma odcień ironiczny, trudno uznać za pejoratywne.

Dość liczną grupę stanowią formacje rzeczownikowe zakończone na - $a$, dodawane bezpośrednio do rdzenia jako końcówka fleksyjna lub też do morfemu sufiksalnego. Żeńska forma sufiksu w nazwach odnoszących się do mężczyzn wzmacnia pejoratywne nacechowanie formacji, jak w przypadku wyrazów: pokraka 'człowiek o krzywych, szeroko rozstawionych nogach', mqdrala 'blagier wiejski a. człowiek chytry, rachujący na łatwowierność ludzką', niedojda 'niezdarny a leniwy mazgaj', zadziora 'kłótnik, awanturnik', wychrzta 'neofita', papla 'gaduła, nie umiejący dochować sekretu'. 
Pozostałe wyrazy zakończone na - $a$ odnoszą się do kobiet lub dzieci. Część tych wyrazów to zapożyczenia z języków obcych. W ich wypadku wykładnikiem emocjonalności jest najczęściej porównanie albo przenośnia sferyczna. Obie motywacje są na ogół bardzo czytelne semantycznie: przybłęda a. znajda 'przybłąkane dziecko lub zwierzę', pucia 'dziewczę a. dziewczak pucołowaty', larwa 'kobieta rozlazła, nieschludna', ję$d z a$ 'nadzwyczaj złośliwa kobieta, czarownica', wiedźma 'stara, złośliwa kobieta', gidja 'kobieta wysoka, lecz niezgrabna'.

Ciekawą i dość liczną grupę wyrazów ekspresywnych tworzą złożenia wyrazowe, które mają najczęściej charakter żartobliwy lub ironiczny. Ekspresywne nazwy dwurdzenne były produktywne już od staropolszczyzny, zwłaszcza w kategorii nazw osób. Wiele nazw złożonych w słownictwie potocznym dziewiętnastego wieku rejestruje słownik wileński. Produktywność złożeń w leksyce ekspresywnej wyjaśnia Kwiryna Handke: „Analityczny charakter tych struktur w zestawieniu z bardziej syntetycznymi derywatami pozwala na zachowanie dokładności, obrazowości i precyzji, z drugiej strony ich większa syntetyczność niż zestawień i innych struktur syntaktycznych wychodzi naprzeciw tendencji do skrótowości i ekonomiczności. Ekspresywna funkcja compositów wynika $\mathrm{z}$ obydwu wymienionych właściwości" ${ }^{12}$. Występujące w materiale słownikowym złożenia to formacje składające $\mathrm{z}$ dwóch semantycznie czytelnych podstaw słowotwórczych, najczęściej połączonych formantem wewnętrznym -o- lub -i-/-y- lub bezspójkowo: ludojad a. ludożerca 'okrutnik, tyran', chorowiek 'człowiek słabowity, schorowany', głodomor 'biedak złakniony', świnopas 'prostak nieokrzesany', robociqż 'robotnik pilny i wytrwały', konowod 'kradnący konie, handlujący końmi skradzionemi', parzygnat 'kucharz', niedopad 'człowiek ruchliwy a niezręczny, potykający się, lecz nie padający', niedowiarek 'każdy niechrześcijanin', urwipołeć 'łobuz', korknos 'człowiek z nosem niepomiernie zadartym', chwalibursa 'chwalca, samochwał', ciamciarymcia 'dziewczę powolne a potulne', paliwoda 'raptus, człowiek porywczy i bez zastanowienia', stabiduda 'organista'.

12 K. Handke, Budowa morfologiczna i funkcja compositów polskich, Wrocław 1976, s. 85. 
Ekspresywne przymiotniki, niesamodzielne pod względem składniowym i semantycznym, służą określeniu rzeczowników, choć są potencjalnie substantywizowane. Ich znaczenie precyzuje zatem kontekst zarówno językowy, jak i pozajęzykowy. Zważywszy na ekspresję samego desygnatu, formacje przymiotnikowe są, jak to często bywa w ludowym słownictwie nacechowanym uczuciowo, względnie neutralne emocjonalnie ${ }^{13}$. Już $w$ samym przekształceniu przymiotnika $w$ rzeczownik kryje się intencja wzmocnienia ekspresywności nazwy, nawet jeśli sufiks tworzący przezwisko jest neutralny.

$\mathrm{W}$ interesującym nas materiale językowym, nacechowane emocjonalnie nazwy przymiotnikowe, występują nierzadko jako synonimy formacji rzeczownikowych: chamacz a. chamaty 'człowiek mówiący niewyraźnie, przez nos'; gadatywus a. gaduszczy 'gaduła'; zadziora a. zadziorzysty 'kłótnik, awanturnik'; korknos a. kurnosy 'człowiek z nosem niepomiernie zadartym'. W roli samodzielnych haseł typu: harkawy 'wymawiający $r$ gardłem, jak Żydzi, Francuzi', krzywy 'niegodziwy', zębaty 'uszczypliwy', żerty 'łakomy', majsterny 'samouk, zdolny do robót ręcznych bez przewodnika i wskazówek', postawny 'człowiek okazały', chitry 'rozgarnięty, pomysłowy', madry 'chytry', spogardliwy 'wyrozumiały' określają pozytywny lub negatywny stosunek nadawcy do opisywanego desygnatu.

Większość czasownikowych formacji ekspresywnych to wyrazy pochodne utworzone afiksalnie od emocjonalnie nacechowanych podstaw werbalnych. Inna rzecz, że czasem trudno jednoznacznie stwierdzić, czy to jedyna motywacja ich ekspresywności. W badanym materiale leksykalnym nacechowane emocjonalnie formy czasownikowe np. ćpać 'jeść łakomie', ćwierzyć się 'mizdrzyć się, trzpiotać się', manić 'obełgiwać, łudzić' dość rzadko związane są z zachowaniem człowieka. Tylko od kilku zanotowanych przez Osipowicza czasowników utworzone zostały ekspresywne derywaty rzeczownikowe. Łączy je to, że odznaczają się większym stopniem ekspresywności niż ich werbalne podstawy, np. peckać 'fuszerować' - peckiel 'fuszer, partacz'; rozdziawić gębę 'otworzyć usta szeroko' - rozdziawiak - 'gap, mający wiecznie otwarte usta'; tłuc 'oddawać się nierządowi' - tłuk 'nierządnica'; wyszczerzać się 'mizdrzyć się,

13 K. Handke, op. cit., s. 36. 
przymilać; dowcipkować' - wyszczerzak 'człowiek ciągle się śmiejący, bufon wioskowy, wyśmiewający wszystkich'.

Najczęściej wykorzystywanym środkiem semantycznym przy tworzeniu nazw ekspresywnych jest, $\mathrm{w}$ badanym materiale, metafora. Proces metaforyzacji obejmuje przede wszystkim przenoszenie na cechy i zachowania ludzi określeń i nazw zakorzenionych w świadomości jako negatywne, a nawet wzbudzające wstręt, odrazę, choć oczywiście występuje też metaforyzacja o małym stopniu pejoratywności. Formacje te są najczęściej bezsufiksalne: łom 'człowiek do niczego niezdatny, dziewka lub kobieta do roboty ociężała', fluk 'Niemiec', parch 'obelż. Żyd', robak 'żyd wiejski porównywany do wilka', sik 'łowiący ryby w łóżku, moczący pod siebie', smyk 'młokos', ziótko 'człowiek podstępny i niebezpieczny', smyk 'młokos', postrzał 'człowiek zapominający się aż do szału, narwany', bęcwał 'człowiek ociężały, leniwy', medyk 'człowiek przebiegły i niebezpieczny', siurek 'pacholę', ubój 'człowiek leniwy do najwyższego stopnia', trzcina 'epitet dawany przez młodzież wiejską miejskiej dziewczynie hożej, wesołej, ponętnej, lecz niedostępnej', pokusa 'wabik, osoba sympatyczna, zbyt pociągająca ku sobie', tłuk 'nierządnica', łyk 'mieszczanin, rolnik, gardzący chłopami; toż klompiarz, krupnik', legat 'ospały, próżniak'. Zdarzają się wśród nich nazwy własne, jak Judasz 'matacz i żartowniś zarazem, ale nieszkodliwy' czy Bucyfał 'człowiek spasły, z twarzą pucołowatą', W określeniu sik wyraźnie uwidacznia się dźwiękonaśladowcza etymologia. Stopień ujemnego nacechowania ekspresywnych rzeczowników zależy od użytych przenośni. Wyrazy piekielnik 'wielki złośnik', paskudnik 'człowiek wstrętny' są derywatami odprzymiotnikowymi, utworzonymi za pomocą dodatnio nacechowanego formantu $-i k$, jednak ich wartość ekspresywna tkwi w przenośnym znaczeniu formacji podstawowej. Dodatnio nacechowane formanty nadają ekspresywnym formacjom pochodnym odcień ironiczny. W przypadku wyrazu odmianek 'dzieciak z niezwykle dużą głową i krzywemi nogami' dodatnio wartościujący sufiks -ek łagodzi nieco pejoratywny wydźwięk formacji.

Dużą ekspresywnością cechuje się też dość liczna grupa różnego typu frazeologizmów. Występują one $\mathrm{w}$ omawianym materiale $\mathrm{w}$ roli wyrazów hasłowych, jak również podhaseł i fragmentów definicji. Najczęściej są to wyrażenia imienne, jak: ostatni grosz 'utracjusz', skow- 
ronek kazionny 'stróż bezpieczeństwa', szczerny wisielec 'istny urwis', krzywy człowiek 'niegodziwiec', muraśka pana Jezusa 'człowiek', duży chłop 'silny mężczyzna'. Sporadycznie zdarzają się zwroty, np. chlastać jęzorem 'obmawiać, szkalować', dufać sobie 'być pewnym siebie', powiedzenia, np. rozgadał się jak drozd na plagę. Zupełną osobliwością jest rymowany wierszyk, będący składnikiem definicji wyrazu niedowiarek: 'Pół psa, pół kozy, niedowiarek boży'.

Na tle licznych ekspresywizmów rodzimych wyraźnie zaznaczają swoją obecność nacechowane ekspresywnie wyrazy obcego pochodzenia. Rzecz jasna, słownictwo zapożyczone niekoniecznie musi być pierwotnie nacechowane emocjonalnie, często nabiera ekspresywności dopiero na gruncie polskim. Część wyrazów przenosi ekspresję z innych języków, ich ekspresywność tkwi w rdzeniu. Najwięcej zapożyczonych nacechowanych emocjonalnie wyrazów w badanym materiale to kresowizmy północno-wschodnie, o białoruskiej lub litewskiej proweniencji, jak: bałdyga 'drab' wołokita 'wałęs, człowiek bez zajęcia', żyża 'człowiek opryskliwy', smerda 'dzieciuch', łachmytka 'kobieta źle prowadząca się', kurdupel 'człowiek małego wzrostu, a pękaty', basałyk 'drągal, próżniak, nicpon', burłak 'chłop Wielkorusin, osiadły na Litwie i Białorusi; kacap, starowierca, filipon'. Dość liczne są też ekspresywne zapożyczenia z języka niemieckiego, np.: mader 'partacz wiejski', rajfurka 'stręczycielka', smurgiel 'smarkacz', sowizdrzat 'awanturnik nieszkodliwy, bufon', szmeker 'przezwisko nadawane niegdyś strażnikom tabacznym', pluder 'żart, toż samo co fluk, wzgardliwe przezwisko nadawane Niemcom', drylag 'dryblas, długi a niezgrabny wyrostek', jak również wyraz klempa 'przezwisko wzgardliwe, oznaczające dziewkę rozlazłą', z którego znaczenia wyraźnie przebija refleks niemiecki (nm. Klampe 'niezgrabny kawał czegoś'). Niezbyt znaczny w interesującym nas zakresie jest udział języka ukraińskiego: hałaburda 'awanturnik', kacap 'burłak, filipon; Wielkorusin', mazepa 'przezwisko osób o szerokiej twarzy, a małych oczach', szałaput 'roztrzepaniec'. Sporadycznie występują także, głównie ogólnopolskie, pożyczki z jidysz: bach a. bachur 'bękart', siksa 'dziewczyna mocząca pod siebie w łóżku; dziewczyna niesympatyczna i złośnica'.

Wyrazy zapożyczone przechodzą często nieoczekiwane ewolucje. Wraz $\mathrm{z}$ ich wnikaniem $\mathrm{w}$ polszczyznę pierwotne znaczenie często ulega zatarciu, a wyraz zaczyna być kojarzony z bardzo różnymi, przypad- 
kowymi znaczeniami, zwykle emocjonalnie nacechowanymi. Tak więc, procesowi zapożyczania towarzyszą zmiany znaczeniowe, polegające głównie na rozszerzaniu znaczeń, deprecjacji semantycznej i pejoratywizacji uczuciowej ${ }^{14}$. Nacechowane emocjonalnie wyrazy obce $w$ słowniczku Osipowiczu wykazują na ogół fonetyczne i morfologiczne przystosowanie do polskiego kontekstu językowego. Otrzymują zwykle polskie końcówki lub afiksy paradygmatów rzeczownikowych.

Słownictwo o antropocentrycznym charakterze, zawarte w Stowniczku gwary augustowskiej A. Osipowicza, przykuwa uwagę swym bogactwem i barwnością. Obejmuje nazwy jednowyrazowe o różnorodnej motywacji, a także związki frazeologiczne, wyrazy rodzime i zapożyczone. Nakładające się na siebie językowe i pozajęzykowe środki ekspresji decydują o tym, że słownictwo określające cechy osobowe i nosicieli tych cech oraz niezgodne $\mathrm{z}$ normą społeczną postawy ma charakter wybitnie ekspresywny, najczęściej z ujemnym nacechowaniem emocjonalnym. Na ukształtowanie takiego właśnie charakteru słownictwa miały wpływ różnorodne czynniki: słowotwórcze - derywacja sufiksalna, semantyczne (metafora), a także czynniki pozajęzykowe ekspresywny charakter samego desygnatu, jak również emocjonalny stosunek nadawcy do inności tego desygnatu.

14 Por. Z. Kurzowa, Polszczyzna Lwowa i Kresów Południowo-Wschodnich do 1939 roku, Warszawa Kraków 1985, s. 305. 